\title{
PENINGKATAN AKTIVITAS ANTIMIKROBA EKSTRAK NANAS (Ananas comosus (L.). Merr) DENGAN PEMBENTUKAN NANOPARTIKEL
}

\author{
Deni Rahmat*, Dian Ratih L., Liliek Nurhidayati, Meilda Ayu Bathini \\ Fakultas Farmasi Universitas Pancasila, Jakarta \\ *Email : mangnden78@yahoo.com
}

\begin{abstract}
ABSTRAK
Bonggol nanas (Ananas comosus (L.). Merr) mengandung enzim bromelain dengan kadar tertinggi dibandingkan bagian nanas lainnya. Salah satu fungsi enzim bromelain adalah sebagai antimikroba. Ekstrak bonggol nanas dibuat dalam bentuk nanopartikel dengan menggunakan kitosan kemudian dikeringkan dengan metode freeze drying. Serbuk kering ekstrak ditentukan Konsentrasi Hambat Minimum (KHM) terhadap Staphylococcus aureus. Nanopartikel ekstrak kering dilakukan uji ukuran partikel, zeta potensial, dan morfologi partikel. Nanopartikel ekstrak kemudian diformulasikan ke dalam bentuk sediaan gel. Tiap formula dilakukan uji mutu fisik antara lain organoleptik, homogenitas, viskositas dan sifat alir dan uji mutu kimia $(\mathrm{pH})$. Hasil penelitian menunjukkan nanopartikel ekstrak memiliki ukuran partikel $60,8 \mathrm{~nm}$ dan bentuk partikel kering sferis. Ekstrak bonggol nanas memiliki KHM pada konsentrasi $1,25 \%$. Gel formula IV menunjukkan DDH tertinggi yaitu $62,5 \mathrm{~mm}$ dan memiliki viskositas dan $\mathrm{pH}$ yang stabil. Dengan demikian pembuatan nanopartikel pada ekstrak bonggol nanas dapat meningkatkan aktivitas antimikroba dalam sediaan gel untuk penggunaan secara topikal
\end{abstract}

Kata kunci: Bonggol nanas, nanopartikel, kitosan, antimikroba

\section{PENDAHULUAN}

Nanas (Ananas comosus. L), berdasarkan informasi dari masyarakat serta buku obat-obatan tradisional, tidak hanya mempunyai nilai ekonomi penting, tetapi juga bermanfaat bagi kesehatan sebagai obat penyembuh penyakit sembelit, gangguan saluran kencing, mual-mual, flu, wasir, kurang darah, penyakit kulit (gatal-gatal, eksim dan kudis) (1). Buah nanas mengandung enzim bromelain, kalsium, fosfor, vitamin A, B, C, lemak, karbohidrat, magnesium, kalium, dekstrosa, sukrosa dan air (2). Kandungan bromelain pada nanas dapat digunakan sebagai antiseptik mulut, antibakteri, antifungi dan desinfektan.

Enzim bromelain merupakan suatu enzim protease yang mampu menghidrolisis ikatan peptida menjadi asam amino. Konsentrasi bromelain yang terdapat pada bonggol nanas lebih tinggi dibanding pada daging buah nanas (3). Selain itu, kandungan vitamin A berfungsi untuk menjaga kesehatan kulit dan memperbaiki sel kulit yang rusak, vitamin $\mathrm{B}$ berfungsi untuk mencegah kerontokan dan vitamin $C$ pada nanas berfungsi untuk memberi nutrisi bagi kulit (2).

Salah satu upaya pengembangan sediaan gel terhadap formulasi ekstrak bonggol nanas tersebut adalah pembentukan nanopartikel dengan bahan pembawa yang dibuat dalam ukuran nanometer. Bahan matriks pembawa obat yang digunakan dalam teknologi nanopartikel salah satunya adalah kitosan. Hal ini bertujuan untuk meningkatkan daya penetrasi, memperlama waktu kontak sehingga meningkatkan efektifitas. 
Penggunaan kitosan dalam bentuk nanopartikel dipilih karena memiliki sifat biokompatibel, biodegradable, toksisitas rendah dan mukoadhesif (3).

Berdasarkan kandungan kimia dan manfaat dari bonggol nanas (Ananas comosus. L) maka dilakukan penelitian dengan memformulasi gel dari ekstrak nanopartikel bonggol nanas (Ananas comosus. L) untuk mengatasi penyakit kulit yang disebabkan oleh bakteri Staphyloccocus aureus. Pada penelitian ini akan dilakukan formulasi dan evaluasi sediaan gel yang mengandung nanopartikel ekstrak bonggol nanas yang mengandung bromelain dengan melakukan uji aktifitas antibakteri terhadap Staphyloccocus dengan bahan pembentuk gel hidroksi propil metil selulosa (HPMC).

\section{METODE}

\section{Bahan}

Bonggol nanas (Ananas comosus.(L.).Merr), kitosan, HPMC, propilen glikol, metil paraben, propil paraben, natrium metabisulfit, suspensi bakteri Staphylococcus aureus, nutrient agar (NA), kaldu pepton, air suling, dapar fosfat $\mathrm{pH} 7, \mathrm{NaOH}, \mathrm{CuSO}_{4}$.

\begin{abstract}
Alat
Homogenizer, freeze dryer, viskometer brookfield tipe RV, alat uji kemampuan menyebar, $\mathrm{pH}$ meter, object glass, timbangan analitik, jarum suntik, particle sizer, pengukur potensial zeta, scanning electron microscope (SEM), jarum ose, labu spiritus, pengaduk magnetik/stirer, laminar air flow, autoklaf, oven, cawan petri, tabung reaksi, inkubator, vortex, serta alat gelas lainnya (presisi dan non presisi).
\end{abstract}

\author{
Pembuatan ekstrak dari bonggol nanas \\ Bonggol nanas yang telah \\ dibersihkan dipotong kecil-kecil \\ ditambahkan buffer fospat $0,1 \mathrm{M} \mathrm{pH} 7$ \\ kemudian dihaluskan dengan \\ menggunakan blender. Hasil blender \\ diperas dan disentrifus dengan kecepatan \\ $3500 \mathrm{rpm}$ selama 15 menit, sehingga \\ diperoleh filtrat.
}

\section{Pembuatan nanopartikel ekstrak bonggol nanas dengan kitosan}

Kitosan sebanyak 1 gram dilarutkan dalam $100 \mathrm{ml}$ asam asetat glasial $1 \%$ menggunakan magnetik stirer sehingga diperoleh larutan induk kitosan 1\%. Ambil $80 \mathrm{ml}$ larutan kitosan $1 \%$ kemudian ditambahkan sedikit demi sedikit ke $100 \mathrm{ml}$ ekstrak bonggol nanas diatas magnetik stirer, kemudian pengadukan dilanjutkan selama 30 menit agar didapat larutan nanopartikel ekstrak bonggol nanas yang stabil.

\section{Evaluasi nanopartikel ekstrak bonggol nanas}

a) Pemeriksaan ukuran partikel

b) Pemeriksaan potensial zeta

c) Pemeriksaan morfologi partikel dengan scanning electron microscope (SEM).

\section{Uji identifikasi bromelain kasar ekstrak dan nanopartikel ekstrak bonggol nanas \\ $3 \mathrm{ml}$ ekstrak bonggol nanas} (sampel) dibuat alkalis dengan $\mathrm{NaOH}$ kemudian ditambahkan larutan $\mathrm{CuSO} 4$ encer. Uji ini memberikan reaksi positif yang ditandai dengan timbulnya warna merah violet atau biru violet.

\section{Penentuan Konsentrasi Hambat Minimum (KHM) ekstrak dan nanopartikel ekstrak bonggol nanas \\ Mikroba uji diremajakan pada media nutrient broth dengan $25 \% \mathrm{~T}$. Uji}


KHM dilakukan dengan metode pengenceran seri pada tabung. Dibuat 10 seri larutan pengenceran ekstrak masingmasing $3 \mathrm{ml}$ kemudian ditanam mikroba uji Staphylococcus aureus yang telah diremajakan dengan jumlah yang sama. Diinkubasi pada suhu $37^{\circ} \mathrm{C}$ selama $18-24$ jam.

Uji aktivitas ekstrak dan nanopartikel ekstrak bonggol nanas secara in vitro

Pengujian aktivitas antimikroba dari serbuk kering nanopartikel bonggol nanas terhadap Staphylococcus aureus dilakukan dengan metode difusi agar menggunakan kertas cakram. Dimasukkan suspensi bakteri $25 \% \mathrm{~T}$ sebanyak $100 \mu \mathrm{l}$ dan $20 \mathrm{ml}$ nutrient agar pada suhu $45-50{ }^{\circ} \mathrm{C}$ pada cawan petri, pembenihan dihomogenkan dan dibiarkan memadat pada suhu kamar. Setelah memadat letakkan kertas cakram yang telah dijenuhkan dengan sediaan yang diuji. Masing-masing cawan petri kemudian diinkubasi dalam keadaan posisi terbalik pada suhu $37{ }^{\circ} \mathrm{C}$ selama 48 jam. Aktivitas antibakteri diamati berdasarkan pengukuran diameter daerah hambat (DDH).

\section{Formulasi gel}

Tabel 1. Formula gel

\begin{tabular}{cccccc}
\hline Bahan & \multicolumn{5}{c}{ Jumlah (\%) } \\
\cline { 2 - 6 } & Blangko & I & II & III & IV \\
\hline Ekstrak bonggol nanas & - & 1 xKHM & - & - & - \\
Nanopartikel ekstrak bonggol nanas & - & - & 1 xKHM & 3 xKHM & 5 xKHM \\
HPMC & 1 & 1 & 1 & 1 & 1 \\
Propilen glikol & 15 & 15 & 15 & 15 & 15 \\
Natrium metabisulfit & 0,1 & 0,1 & 0,1 & 0,1 & 0,1 \\
Metil paraben & 0,1 & 0,1 & 0,1 & 0,1 & 0,1 \\
Propil paraben & 0.02 & 0.02 & 0.02 & 0.02 & 0.02 \\
NaOH & ad pH 7 & ad pH 7 & ad pH 7 & ad pH 7 & ad pH 7 \\
Aquadest ad & 100 & 100 & 100 & 100 & 100 \\
\hline
\end{tabular}

Hidroksi propil metil selulosa dikembangkan didalam air suling suhu 60$70{ }^{\circ} \mathrm{C}$, kemudian tambahkan ekstrak bonggol nanas atau nanopartikel ekstrak yang telah dicampurkan dengan propilen glikol. Tambahkan dengan metil paraben, propil paraben dan natrium metabisulfit. $\mathrm{pH}$ diatur dengan $\mathrm{NaOH}$ sampai $\mathrm{pH} 7$. Campuran diaduk sampai homogen. Gel yang terbentuk dievaluasi organoleptik, homogenitas, viskositas dan $\mathrm{pH}$ selama 1 bulan.

\section{HASIL DAN DISKUSI}

Tanaman nanas yang digunakan dalam penelitian ini diperoleh dari pasar Cisalak, Depok. Nanas yang digunakan adalah nanas yang sudah matang. Bagian yg diambil dari buah nanas adalah bonggolnya yang sudah dicuci kemudian dipotong-potong untuk dijadikan ekstrak dan nanopartikel. Pemeriksaan ukuran partikel larutan nanopartikel ekstrak bonggol nanas menggunakan alat Delsa ${ }^{\mathrm{TM}}$ Nano dengan hasil pengukuran pada Table 2. 
Tabel 2. Hasil uji pemeriksaan ukuran partikel

\begin{tabular}{ccc}
\hline Pengujian & Rata-rata Diameter Partikel $(\mathrm{nm})$ & Standard Deviasi \\
\hline 1 & 51.9 & 13.2 \\
2 & 64.9 & 16.7 \\
3 & 65.6 & 17.1 \\
\hline Rata-rata & 60.8 & - \\
\hline
\end{tabular}

Suatu partikel dikatakan memiliki ukuran nanopartikel jika diameter partikel berukuran 10-1000 nm. Data hasil uji pemeriksaan ukuran partikel pada suspensi nanopartikel ekstrak bonggol nanas menunjukan ukuran partikel yang memenuhi syarat yaitu 51.9; 64.9, dan $65.4 \mathrm{~nm}$ sehingga nanopartikel ekstrak bonggol nanas memenuhi persyaratan. Distribusi ukuran partikel dinyatakan dalam indeks polidispersitas. Rentang indeks polidispersitas berada antara 0 sampai dengan 1 . Nilai indeks polidispersitas mendekati 0 menunjukkan dispersi yang homogen. Sedangkan indeks polidispersitas dengan nilai lebih dari 0,5 menunjukkan heterogenitas yang tinggi. Hasil dari nanopartikel ekstrak bonggol nanas memiliki indeks polidispersitas sekitar 0,426-0,479 sehingga nanopartikel ekstrak bonggol nanas menunjukkan dispersi yang relatif homogen.

Tabel 3. Hasil uji potensial zeta

\begin{tabular}{cc}
\hline Pengujian & Zeta Potensial $(\mathrm{mV})$ \\
\hline 1 & 368.05 \\
2 & 364.36 \\
Rata-rata & 364,21 \\
\hline
\end{tabular}

Pemeriksaan potensial zeta suspensi nanopartikel ekstrak bonggol nanas menggunakan alat Delsa ${ }^{\mathrm{TM}}$ Nano dengan hasil tertera pada Tabel 3 . Semakin besar kekuatan tolak menolak antar partikel maka semakin kecil kemungkinan partikel bergabung dan membentuk agregat. Efek ini berhubungan dengan pengikatan gugus anionik oleh gugus amin yang panjang dari kitosan untuk menjaga nilai elektrik yang tinggi sehingga dapat mencegah terjadinya agregasi. Nanopartikel dengan nilai potensial zeta lebih dari $+/-30 \mathrm{mV}$ telah terbukti stabil yang dapat mencegah terbentuknya agregasi. Data hasil uji potensial zeta larutan nanopartikel ekstrak bonggol nanas menunjukkan rata-rata potensial $364,21 \mathrm{mV}$. Nilai yang tinggi ini diakibatkan oleh kehadiran komponen dapar fosfat dalam ekstrak.

Pemeriksaan morfologi partikel dilakukan dengan menyiapkan $1 \mathrm{~g}$ serbuk nanopartikel ekstrak bonggol nanas hasil pengeringan dengan menggunakan alat Scanning Electron Microscope (SEM).Hasil pemeriksaan morfologi partikel dari nanopartikel ekstrak bonggol nanas dapat dilihat pada Gambar 1 dimana menunjukkan partikel yang berbentuk sferis dan berukuran lebih besar akibat adanya penumpukan partikel yang jumlahnya banyak. 


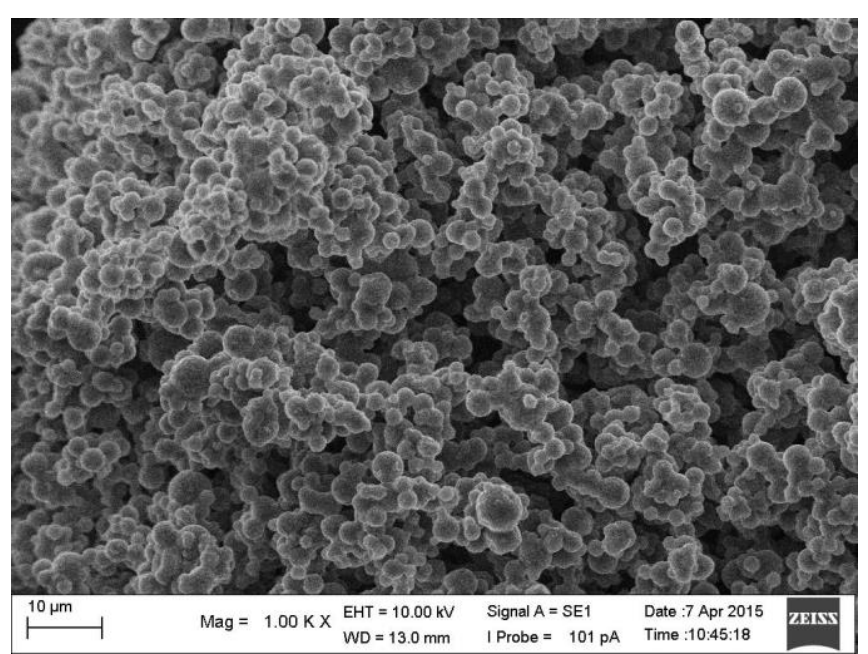

Gambar 1. Morfologi partikel kering

Tabel 4. Hasil Pemeriksaan Organoleptik Serbuk

\begin{tabular}{ccccc}
\hline Jenis Ekstrak & Warna & Bau & Rasa & Sifat Serbuk \\
\hline Nanopartikel Ekstrak & Kuning & Bau khas asam & Manis & Halus, \\
Bonggol Nanas & kecoklatan & yang kuat \\
Ekstrak Bonggol & Coklat tua & Bau khas asam \\
Nanas & & Mang kuat & Manis & $\begin{array}{c}\text { Higroskopis, } \\
\text { agak lengket }\end{array}$ \\
\hline
\end{tabular}

Tabel 5. Hasil Pengamatan Konsentrasi Hambat Minimum

\begin{tabular}{cc}
\hline Konsentrasi $(\%)$ & Hasil Pengamatan \\
\hline 10 & - \\
5 & - \\
2.5 & - \\
1.25 & - \\
0.625 & + \\
0.3125 & + \\
0.1563 & + \\
0.0781 & + \\
0.0391 & + \\
0.0195 & + \\
\hline
\end{tabular}

Keterangan

+: adanya pertumbuhan bakteri

- : tidak terjadi pertumbuhan bakteri

Konsentrasi Hambat minimum digunakan untuk menentukan dosis ekstrak bonggol nanas secara kualitatif. Dibuat seri pengenceran kaldu pepton dengan 10 konsentrasi yang berbeda dan diinkubasi pada suhu $37^{\circ} \mathrm{C}$ selama 24 jam.
Pengamatan setelah inkubasi dapat dilihat pada Tabel 5.

Dari hasil pengamatan dapat disimpulkan bahwa pada konsentrasi 10 , $5,2.5$, dan $1.25 \%$ didapat hasil (-) yang artinya tidak terjadi pertumbuhan bakteri. 
Sehingga dapat ditetapkan Konsentrasi Hambat Minimum ekstrak bonggol nanas terhadap bakteri Staphylococcus aureus adalah $1,25 \%$.

Uji KHM kemudian dilanjutkan secara kuantitatif dengan uji Diameter Daerah Hambat (DDH) yang menggunakan metode difusi agar dengan kertas cakram yang telah dijenuhkan selama 15 menit didalam ekstrak dan nanopartikel ekstrak bonggol nanas dengan konsentrasi $1.25 \%$. Kemudian kertas cakram tersebut diletakkan diatas Nutrient Agar yang telah dihomogenkan dengan suspensi bakteri terlebih dahulu lalu diinkubasi selama 24 jam pada suhu $37{ }^{\circ} \mathrm{C}$. Daerah bening yang terlihat disekitar kertas cakram menunjukkan zona hambat bakteri. Hasil DDH ekstrak dan nanopartikel ekstrak bonggol nanas dapat dilihat pada Tabel 6.

Tabel 6. Hasil Uji Diameter Daerah Hambat ekstrak dan nanopartikel ekstrak bonggol nanas pada konsentrasi $1.25 \%$

\begin{tabular}{ccc}
\hline $\begin{array}{c}\text { Kertas } \\
\text { Cakram }\end{array}$ & $\begin{array}{c}\text { DDH Ekstrak Bonggol } \\
\text { Nanas 1.25\% }(\mathrm{mm})\end{array}$ & $\begin{array}{c}\text { DDH Nanopartikel Ekstrak } \\
\text { Bonggol Nanas 1.25\% }(\mathrm{mm})\end{array}$ \\
\hline 1 & $18 \pm 3,15$ & $22.75 \pm 3,56$ \\
2 & $17.25 \pm 2,79$ & $23.55 \pm 2,84$ \\
3 & $16.75 \pm 4,57$ & $22.80 \pm 3,56$ \\
4 & $17.25 \pm 2,95$ & $23 \pm 2,87$ \\
\hline Rata-rata & $17.3125 \pm 4,11$ & $23.025 \pm 3,86$ \\
\hline
\end{tabular}

Berdasarkan data DDH ekstrak dan nanopartikel ekstrak bonggol nanas dapat dilihat bahwa dalam ukuran nanopartikel ekstrak bonggol nanas menghasilkan zona hambat yang lebih besar dibandingkan dengan ekstrak bonggol nanas.

Uji stabilitas fisik gel ekstrak dan nanopartikel ekstrak bonggol nanas dilakukan pada suhu kamar dan $4{ }^{\circ} \mathrm{C}$ selama satu bulan. Uji stabilitas dilakukan terhadap formula blangko, I, II, III dan IV mulai dari minggu 0 sampai dengan minggu ke 4. Pengamatan uji stabilitas fisik gel meliputi organoleptik, viskositas dan sifat alir dan $\mathrm{pH}$. Hasil pengamatan uji organoleptik gel bonggol nanas dapat dilihat pada Tabel 7.

Tabel 7. Hasil Pengamatan organoleptik gel ekstrak dan nanopartikel ekstrak bonggol nanas

\begin{tabular}{cccccccc}
\hline \multicolumn{2}{c}{ Formula } & \multirow{2}{*}{ Organoleptik } & \multicolumn{5}{c}{ Waktu (minggu) } \\
\cline { 3 - 7 } & & & 0 & 1 & 2 & 3 & 4 \\
\hline Blangko & $25^{\circ} \mathrm{C}$ & Warna & Jernih & Jernih & Jernih & jernih & Jernih \\
& & Bau & Lemah & Lemah & Lemah & Lemah & Lemah \\
& \multirow{2}{*}{$4^{\circ} \mathrm{C}$} & Warna & Jernih & Jernih & jernih & jernih & Jernih \\
& & Bau & Lemah & Lemah & Lemah & Lemah & Lemah \\
I & $25^{\circ} \mathrm{C}$ & Warna & Kuning & Kuning & Kuning & Kuning & Kuning \\
& & & muda & muda & muda & muda & muda \\
& & Bau & Lemah & Lemah & Lemah & Lemah & Lemah \\
& $44^{\circ} \mathrm{C}$ & Warna & Kuning & Kuning & Kuning & Kuning & Kuning \\
& & & muda & muda & muda & muda & muda \\
& & Bau & Lemah & Lemah & Lemah & Lemah & Lemah \\
\hline
\end{tabular}


Berdasarkan data diatas, semua formula tidak mengalami perubahan organoleptik berupa warna dan bau setelah dilakukan pengamatan selama satu bulan pada suhu kamar dan $4{ }^{\circ} \mathrm{C}$. Sehingga, secara organoleptik sediaan gel dinyatakan stabil.

Uji homogenitas dimaksudkan untuk mengetahui apakah sediaan gel yang dibuat tercampur homogen atau tidak. Uji ini dilakukan dengan mengoleskan sediaan pada kaca objek yang direkatkan dengan kaca objek lain kemudian dilihat homogenitasnya. Sediaan gel baik yang disimpan pada suhu kamar maupun pada suhu penyimpanan 4 ${ }^{\circ} \mathrm{C}$ homogen setelah dilakukan pengamatan dari minggu 0 sampai minggu ke 4.

Viskositas sediaan gel ekstrak dan nanopartikel ekstrak bonggol nanas didapat dengan menggunakan viskometer Brookfield. Data dapat dilihat pada Tabel 8.

Tabel 8.. Hasil evaluasi viksositas sediaan gel

\begin{tabular}{ccc}
\hline \multicolumn{2}{c}{ Formula } & $\begin{array}{c}\text { Viskositas (Poise) } \\
\text { RPM 10 }\end{array}$ \\
\hline Blangko & $25^{\circ} \mathrm{C}$ & $4300 \pm 5,88$ \\
& $4^{\circ} \mathrm{C}$ & $4300 \pm 4,54$ \\
I & $25^{\circ} \mathrm{C}$ & $3450 \pm 3,23$ \\
& $4^{\circ} \mathrm{C}$ & $3750 \pm 2,70$ \\
II & $25^{\circ} \mathrm{C}$ & $3250 \pm 3,03$ \\
& $4^{\circ} \mathrm{C}$ & $3550 \pm 7,55$ \\
III & $25^{\circ} \mathrm{C}$ & $3000 \pm 0,00$ \\
& $4^{\circ} \mathrm{C}$ & $3500 \pm 5,55$ \\
IV & $25^{\circ} \mathrm{C}$ & $2800 \pm 0,00$ \\
& $4{ }^{\circ} \mathrm{C}$ & $3300 \pm 5,88$ \\
\hline
\end{tabular}

Berdasarkan hasil pengamatan grafik viskositas gel ekstrak dan nanopartikel ekstrak bonggol nanas pada rpm 10 dapat diamati bahwa kelima formula mengalami peningkatan viskositas pada suhu penyimpanan $4{ }^{\circ} \mathrm{C}$. Hal ini disebabkan karena suhu dapat mempengaruhi viskositas sediaan.

Hasil analisis viskositas menggunakan ANOVA dua arah menunjukan bahwa pada blangko, formula II, III dan IV menunjukan p-value $>0,05$ terhadap waktu dan suhu artinya tidak ada perbedaan bermakna antara formula terhadap waktu penyimpanan selama 4 minggu maupun terhadap suhu penyimpanan $25^{\circ} \mathrm{C}$ atau $4{ }^{\circ} \mathrm{C}$. Sedangkan pada formula I menunjukkan p-value $<0,05$ terhadap waktu penyimpanan dan suhu yang artinya ada perbedaan bermakna antara formula I terhadap waktu dan suhu penyimpanan.

Hasil uji pH dimaksudkan untuk mengetahui apakah $\mathrm{pH}$ sediaan gel stabil selama penyimpanan pada suhu kamar dan suhu $4{ }^{\circ} \mathrm{C}$ selama 1 bulan. $\mathrm{pH}$ yang diatur agar sesuai dengan $\mathrm{pH}$ kulit.

Berdasarkan data hasil uji ANOVA dua arah menunjukkan bahwa pada blangko, formula I, II, dan IV menunjukan p-value $>0,05$ terhadap waktu dan suhu artinya tidak ada perbedaan bermakna antara blangko, formula I, II dan IV terhadap waktu penyimpanan selama 4 minggu maupun terhadap suhu penyimpanan $25^{\circ} \mathrm{C}$ atau 4 ${ }^{\circ} \mathrm{C}$. Sedangkan formula III menunjukkan p-value $<0,05$ terhadap suhu yang artinya ada perbedaan bermakna antara formula 
III terhadap suhu penyimpanan $25^{\circ} \mathrm{C}$ dan $4{ }^{\circ} \mathrm{C}$ dan p-value $>0,05$ terhadap waktu yang artinya tidak ada perbedaan bermakna antara formula III terhadap waktu penyimpanan 4 minggu.

Uji DDH terhadap gel dilakukan untuk mengetahui apakah ada perubahan aktivitas anti mikroba dari ekstrak dan nanopartikel ekstrak bonggol nanas sebelum dan sesudah di formulasi. Hasil uji DDH sediaan gel dapat diamati pada Tabel 9.

Tabel 9. Hasil uji DDH pada sediaan gel

\begin{tabular}{cc}
\hline Formula & DDH $(\mathrm{mm})$ \\
\hline Blangko & $0 \pm 0,00$ \\
I & $16.90 \pm 2,52$ \\
II & $22.60 \pm 3,30$ \\
III & $42.00 \pm 4,26$ \\
IV & $62.5 \pm 3,67$ \\
\hline
\end{tabular}

Berdasarkan data uji DDH sediaan gel dapat dilihat ada sedikit penurunan aktivitas antimikroba pada formula I (yang mengandung ekstrak bonggol nanas 1xKHM) yaitu sebelum diformulasi didapati DDH 17.3125 \pm 4.11 $\mathrm{mm}$ menjadi $16.90 \pm 2.52 \mathrm{~mm}$ setelah diformulasi. Begitupun pada formula II (yang mengandung nanopartikel ekstrak bonggol nanas 1xKHM) didapati penurunan aktivitas yaitu sebelum di formulasi didapati DDH $23.025 \pm 3.86$ $\mathrm{mm}$ menjadi $22.60 \pm 3.30 \mathrm{~mm}$ setelah diformulasi. Pada blangko tidak didapati adanya zona hambat bakteri dikarenakan pada blangko tidak mengandung ekstrak atau nanopartikel ekstrak bonggol nanas. Sedangkan pada formula III (yang mengandung nanopartikel ekstrak bonggol nanas $3 \mathrm{x}$ KHM) didapat $\mathrm{DDH}$ $42.00 \mathrm{~mm}$ dan pada formula IV (yang mengandung nanopartikel ekstrak bonggol nanas $5 \mathrm{xKHM}$ ) didapat $\mathrm{DDH}$ $62.5 \mathrm{~mm}$.

Hasil uji DDH berdasarkan hasil ANOVA satu arah menunjukkan bahwa pvalue $<0,05$ yang artinya ada perbedaan bermakna antara DDH dari tiap formula. Setelah diuji lebih lanjut terlihat bahwa semua DDH formula berbeda bermakna dengan formula lainnya dengan $\mathrm{p}$-value $<0,05$. Hal ini menunjukkan bahwa konsentrasi nanopartikel ekstrak mempengaruhi DDH sediaan.

\section{KESIMPULAN}

1. Ekstrak bonggol nanas dapat dijadikan nanopartikel dengan menggunakan kitosan $1 \%$ dengan dapar fosfat $\mathrm{pH} 7$ dengan rata-rata ukuran partikel 60,8 nm.

2. Ekstrak bonggol nanas memiliki aktivitas antibakteri terhadap Staphylococcus aureus dengan Konsentrasi Hambat Minimum (KHM): 1,25\% dan Diameter Daerah Hambat (DDH) sebesar 17,3125 \pm $4,11 \mathrm{~mm}$.

3. Aktivitas antibakteri nanopartikel menunjukkan Diameter Daerah Hambat (DDH) 23,025 $\pm 3,86 \mathrm{~mm}$.

\section{DAFTAR PUSTAKA}

1. Anggraini D, Rahmides WS, Malik M. Formulasi Sabun Cair dari Ekstrak Batang Nanas (Ananas comosus.L) untuk Mengatasi Jamur Candida albicans. Riau: Sekolah Tinggi Ilmu Farmasi Riau. Padang: Fakultas Farmasi Universitas Andalas Padang; 2012. h.30.

2. Putra AR. Formulasi Sampo Ekstrak Buah Nanas Dengan Variasi Konsentrasi HPMC Sebagai Pengental Dan Penstabil Busa. Jakarta: Fakultas Farmasi Universitas Pancasila; 2010.

3. Rahayu A. Formulasi Tablet Dari Nanopartikel Ekstrak Daun Sambiloto (Andrographis paniculata [Burm.f.] Ness) Dengan Metode Cetak Langsung. Jakarta: Fakultas Farmasi Univeristas Pancasila; 2014.

4. Kantor Deputi Menegristek Bidang Pendayagunaan dan Pemasyarakatan Ilmu Pengetahuan dan Teknologi.Ttg Budidaya Pertanian. Jakarta: Kantor 
Deputi Menegristek Bidang Pendayagunaan dan Pemasyarakatan Ilmu Pengetahuan dan Teknologi; 2000. h. 1-17.

5. Tranggono RI, Latifah F. Buku Pegangan Ilmu Pengetahuan Kosmetik. Jakarta: PT Gramedia Pustaka Utama; 2006. h.33-35;132133.

6. Alternative Medicine Review. Bromelain Monograph; 2010. Vol 15. No 4. p. 361-364.

7. Achmad N. Reaksi Analisa Protein. 2011. h. 1-2.

8. Sinaga SR. Uji Banding Efektivitas Perasan Jeruk Purut (Citrus hystrix
DC) dengan Zinc Pyrithione 1\% Terhadap Pertumbuhan Pityrosporum ovale pada Penderita Berketombe. Semarang: Fakultas Kedokteran Universitas Diponegoro; 2012. h.1,89.

9. Holt JG, Krieg NR, Sneath PHA, Staley JT, Williams ST. Bergey's Manual of Determinative Bacteriology Ninth Edition. Baltimore: William \& Wilkins; 1994.

10. Lachman L, Lieberman HA. Pharmaceutical Dosage Forms, Vol. 1. New York: Marcel Dekker; 1980. 